\title{
A infância e o processo de ensino- aprendizagem entre os Guarani Mbya: jogo, música e educação
}

Childhood and the process of teaching and learning among the Guarani Mbya: game, music and education

Daisy Fragoso* daisy.fragoso@usp.br 


\section{Resumo}

Este texto apresenta e discute brevemente como a concepção de ensino-aprendizagem entre as crianças Guarani Mbya refletia no modo como estas, enquanto colaboradoras de trabalho de pesquisa etnomusicológica, ensinavam suas canções ao pesquisador em questão. Discorre-se, ainda, sobre os desafios encontrados durante o trabalho de campo realizado, no que diz respeito ao processo de ensino-aprendizagem entre a cultura guarani. Os caminhos percorridos durante a superação de tais desafios trazem à luz a maneira como os Guarani concebem a infância e, em consequência disso, como suas crianças aprendem - e ensinam -, o que pode remeter a análises relacionadas ao jogo ideal deleuziano.

Palavras-chave: Cultura guarani; Crianças Guarani; Jogo ideal; Educação Musical.

\section{Abstract}

This text briefly presents and discusses how the concept of teaching-learning among Guarani Mbya children was manifest in the way they, as collaborators in an ethnomusicological research work, taught their songs to the researchers. It also discusses cultural challenges encountered in the teaching and learning process among the guarani during the fieldwork. The paths taken in order to overcome these challenges bring to light the Guarani conception of childhood and, as a consequence, clarify how their children learn - and teach - reminding us of analyses regarding the ideal Deleuzian game.

Keywords: Guarani culture; Guarani children; Ideal game; Music education. 


\section{A primeira história}

- Eu ainda não conheço essa canção que você está cantando. Você pode me ensinar? - pergunto a Jade Jaxuka ${ }^{1}$, criança Guarani Mbya $^{2}$ de aproximadamente onze anos de idade.

Jade canta a canção inteira outra vez.

Sem conseguir entender as palavras do que era cantado em função de eu falar Guarani bem pouco ainda, peço à menina:

- Que palavra você disse depois de $\mathrm{mboi}^{3}$ ?

Jade não me diz a palavra, mas volta a cantar a canção inteira.

- Sobre o que é a canção, Jade?

- É do Tadeu.

Sua tia, mãe do Tadeu, explica:

- As crianças fizeram essa música porque o Tadeu não deixava ninguém pegar sua cobrinha de estimação, nem sua camisa do Santos ${ }^{4}$.

Jade repete a canção.

- Você disse "nome xe xevy"? - pergunto novamente, pois queria transcrever a canção.

Jade recomeça a canção. Então, mesmo sem saber o texto, juntei-me como pude a ela, e seguimos o caminho.

\section{O contexto do trabalho}

Entre os anos de 2013 e 2015, foi desenvolvida uma pesquisa de mestrado ${ }^{6}$ cujo principal objetivo era analisar as relações musicais e sociais que um grupo infantil guarani e outro não indígena ${ }^{7}$ estabeleceram entre si. Tal análise possibilitou a discussão sobre a maneira como as crianças envolvidas rearranjaram suas impressões acerca das relações com indivíduos de culturas diferentes, bem como ofereceu espaço para que se indicassem as razões pelas quais se julga relevante incluir canções de diferentes povos e culturas no repertório escolar e/ou coral.

$1 \quad$ Os Guarani Mbya recebem dois nomes: um em português e outro em guarani. O primeiro nome é dado pelos pais na ocasião do nascimento de seu filho; já o segundo é dado pelo xeramoĩ (xamã) da aldeia em ritual específico - o nhemongarai.

2 Os Guarani que vivem no Brasil são divididos em Guarani Mbya, Guarani Ñandeva e Guarani Kaiowá, e diferem entre si quanto à língua, quanto à cosmologia, quanto à música etc. Neste trabalho, tratamos dos Guarani Mbya. Assim, quando houver referência aos Guarani, deve-se subentender "Guarani Mbya".

3 Tradução literal do guarani para o português: cobra.

$4 \quad$ Santos, o time de futebol.

5 Expressão escrita propositalmente com erro de ortografia, indicando a não compreensão do pesquisador, naquele momento, em relação ao que a criança cantava. O correto é "no me xe xevy", cuja tradução é "eu peguei/tomei para mim".

6 Pesquisa de Mestrado em Artes, na área de Musicologia, realizada entre 2013 e 2014, no Programa de Pós-Graduação em Música da Universidade de São Paulo, intitulado "Entre a opy e a sala de música: arranjos entre crianças Guarani Mbya e crianças não indígenas", sob orientação do Prof. Dr. Pedro Paulo Salles.

$7 \quad 0$ grupo não indígena era formado por 17 crianças entre 5 e 11 anos. Este era um grupo coral infantil de um centro comunitário localizado na zona sul da cidade de São Paulo. Sobre o grupo indígena serão feitas considerações ao longo do texto. 
Dessa intenção maior viriam outras duas: apresentar e discutir as estratégias didáticas usadas na abordagem desse repertório/conteúdo com as crianças não indígenas participantes da pesquisa e reunir algumas canções guarani Mbya que pudessem ser usadas em contextos de ensino formal ou informal. Assim, diante destes três grandes objetivos, foram promovidos encontros periódicos, durante os anos da pesquisa, entre os dois grupos na aldeia guarani Tenondé Porã, no extremo sul da cidade de São Paulo e fora dela, para que as crianças cantassem e brincassem juntas, para que compartilhassem experiências.

Estes momentos compartilhados entre as crianças dos dois grupos durante pouco mais de dois anos eram precedidos e alternados com trabalho de campo realizado por mim. Isto é, além das visitas que as crianças não indígenas faziam à aldeia, outras visitas eram feitas por mim, individualmente, a fim de encontrar material que pudesse ser trabalhado com este grupo e para levantar dados sobre a música que as crianças Guarani dessa aldeia cantavam - e faziam - e sobre suas dinâmicas socioculturais.

Ainda que as discussões se voltassem, na maioria das vezes, para o campo da Educação Musical, a pesquisa, de caráter etnográfico, inevitavelmente transitou entre outras áreas, tais como a Antropologia, a Sociologia, a Educação e a Etnomusicologia, e dialogou com elas. No entanto, neste texto, apresentarei e discutirei o modo como a concepção de infância e de aprendizagem dos Guarani se refletia na maneira como essas crianças me ensinavam suas canções.

\section{Kyrĩgue'i japoraei! (Crianças, vamos cantar!)}

Quanto à busca de canções, a ideia era que os principais colaboradores fossem as crianças Guarani. No entanto, ao final do trabalho, formávamos, adultos e crianças Guarani e eu, um grupo só na $o p y^{8}$, onde os Guarani ensinavam a mim as canções que achavam que eu deveria aprender. Ainda que eu ficasse, com bastante frequência, entre os adultos, a maior parte do meu tempo era dedicada a estar com as crianças Guarani. Elas me levavam por longos passeios pela aldeia, enquanto me ensinavam tudo o que achavam pertinente: brincadeiras, brinquedos, músicas, língua, cosmologia etc.

Nessa tekoa ${ }^{9}$, habitam cerca de mil Guarani. Mas, ainda que eu tenha conhecido algumas famílias por lá, o grupo infantil indígena que me acompanhava era composto por parentes diretos do xeramoĩ, ou seja, estes eram seus filhos, filhas, netos e netas. Quanto à palavra xeramoĩ, esta se refere ao nome pelo qual são chamados os xamãs (MACEDO, 2013, p. 190), mas sua tradução literal, de acordo com o dicionário organizado por Dooley (1998), é "meu avô". Já os Guarani traduzem essa palavra aos jurua ${ }^{10}$ como "pajé". Da junção dessas três definições, temos que xeramoĩ é um homem mais velho, não necessariamente idoso, responsável pelos rituais e pela conexão com Nhan-

\footnotetext{
$8 \quad$ Casa de reza.

$9 \quad$ Aldeia.

10 Termo usado pelos Guarani para se referir ao branco. No Guarani paraguaio, a palavra juru'a significa "bigode" e tem a mesma função que no Guarani Mbya.
} 
deru, demiurgo guarani. O xeramoĩ é também um conselheiro a quem as pessoas da aldeia respeitam. No caso do meu grupo de trabalho, xeramoĩ era tanto xamã quanto pai ou avô das crianças.

Foi o xeramoĩ a primeira pessoa que conheci na aldeia, justamente pelo papel que desempenhava na comunidade: ele era tanto o responsável pelo coro quanto pela família que o compunha. Também foi com ele que conversei sobre o trabalho de pesquisa que pretendia realizar; e foi dele o primeiro consentimento. Na primeira visita, o xeramoĩ me apresentou a algumas crianças, às quais perguntei se poderiam me ajudar com a pronúncia e tradução da canção "Kyrĩgue'i peju jajerojy" ("Vamos, crianças, dançar"). Esta era uma canção que eu pretendia ensinar para os meus alunos não indígenas, participantes da pesquisa, para o primeiro encontro dos grupos que aconteceria em algumas semanas. Escolhi esta música a partir de um $\mathrm{CD}^{11}$ gravado há alguns anos por outros grupos Guarani, motivada pelo que gostaria de ensinar mais tarde ao grupo infantil não indígena, a partir do seguinte critério: o texto da canção era curto e, tanto o texto quanto a melodia eram repetidos algumas vezes. Assim, tendo em vista o que gostaria de aprender, pedi às crianças que me ensinassem a pronúncia, a escrita e a tradução da canção. Esta era uma necessidade minha, afinal, para mim, parecia imprescindível, naquele momento, ter acesso à forma escrita da canção, pois só assim, imaginava, seria capaz de traduzi-la e pronunciá-la corretamente.

Tomando essa primeira experiência como base e considerando que as crianças Guarani sabiam que eu estava ali para ouvir e aprender canções que seriam ensinadas ao grupo não indígena, imaginei que as demais canções compartilhadas comigo na aldeia seriam ensinadas a mim dessa maneira: eu perguntaria e elas me responderiam. Com isso em mente, retornei à aldeia para que aprendesse mais canções, mas, dessa vez, sem uma canção escolhida por mim.

Com este pensamento, pedi, na visita seguinte, que me ensinassem uma canção de que gostassem. Imediatamente, começaram a cantar uma canção. Pedi que me ensinassem em partes, ou que me dissessem a letra, ou que a escrevessem, mas cada pedido era sucedido pela repetição da canção inteira, ou, quando muito, eram-me fornecidas informações bastante genéricas, como, por exemplo, "esta canção é do peixinho" (FRAGOSO, 2015, p. 66).

O tempo ia passando e eu tinha a sensação de que eu não progredia quanto ao que me propusera a fazer. Por isso, decidi mudar de estratégia: pedi às crianças Guarani que desenhassem a canção, de modo que eu pudesse recolher pistas sobre o que se referia a letra dessa música. Assim, entreguei às crianças tintas, canetinhas, gizes de cera, lápis de cor e papel, e, na medida em que iam desenhando, eu as ia interrogando:

- Você está desenhando que música? - pergunto a uma das crianças Guarani.

- Estou desenhando Oreru.

- Sobre o que é a música Oreru?

11 FONSECA, Maurício (Coord.). TUPÃ, Marcos dos Santos; POPYGUA, Timóteo Verá; VERÍSSIMO, Valdelino Karai; POTY, Manoel Lima Karai; JEKUPÉ, Olívio (Coord. indígena). Ñande Arandu Pygua - Memória viva guarani. São Paulo: Estúdio Zabumba, Instituto Teko Arandu, 2004. CD - partes 1 e 2. 
- É sobre Nhamandu. Esse é Nhamandu - diz a criança apontando para o sol que desenhara.

- Ah, Nhamandu é o sol?

- Não. Nhamandu é Nhamandu ${ }^{12}$.

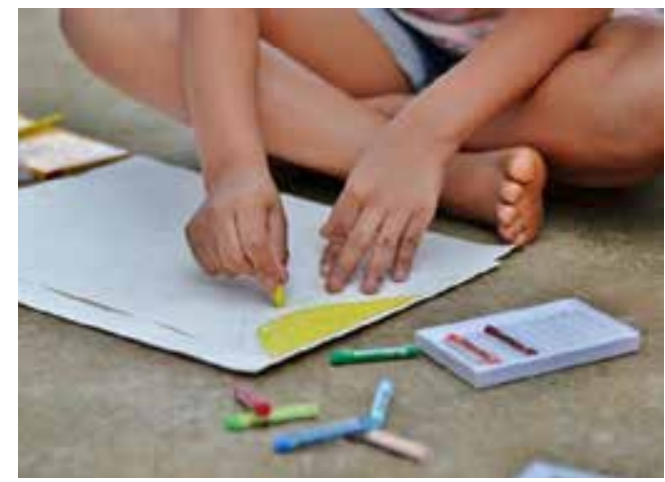

Fig.1. Desenho feito por uma das crianças Guarani para ilustrar a canção "Oreru Nhamandu Tupã" (FRAGOSO, 2015, p. 91).

Este caminho permitiu que informações menos genéricas sobre as canções fossem divididas comigo. Em seguida, fui escrevendo a letra da canção do jeito que eu entendia, provocando nas crianças Guarani a necessidade de, chamando minha atenção para a pronúncia, corrigirem os erros ortográficos que identificavam: "Não é api; é apy!" (na língua guarani, a letra "I" tem som totalmente diferente da letra "Y", mas pode passar despercebido a alguns daqueles cujo português é a língua materna). Mesmo assim, elas não diziam que eu deveria trocar a letra "i" pela letra " $y$ ". Apenas pronunciavam a palavra e eu deveria saber quais correções fazer. Se eu não soubesse, elas deixavam como estava.

Partindo disso, ainda que com muito custo, reunia todas as informações que recolhia e tentava escrever e traduzir o texto. Para mim, este registro era uma ferramenta importante no meu aprendizado, pois eu entendia que só conseguiria pronunciar corretamente o texto e traduzir mais fielmente a canção se as palavras estivessem grafadas como no dicionário que eu consultava. Além disso, em se tratando de material que pudesse ser disponibilizado para uso em contextos escolares, era fundamental que as transcrições das canções contassem com texto, tradução e pronúncia corretos ${ }^{13}$.

Quando mostrei às crianças guarani que eu sabia cantar a música que haviam cantado para mim, elas, felizes com o resultado, pediram que eu cantasse outra. Mas eu não sabia outra, levando-as a me mostrar uma nova canção. Como da outra vez, pedi que me ensinassem esta canção; e, como da outra vez, elas cantavam a música toda e rejeitavam o meu pedido de me ensinar frase a frase, de modo que, novamente, eu ia recolhendo pistas sobre a canção até chegar ao texto correto para, então, apresentar-

\footnotetext{
12 Nhamandu é um ser sobrenatural. Quando os Guarani explicam aos jurua quem é Nhamandu, é Ihes dito que Nhamandu é o Deus Sol (FRAGOSO, 2015, p. 51 e 57).

13 Entende-se aqui que, em se tratando de trabalho desenvolvido com canções de diferentes culturas em contextos escolares, é preciso haver algum diálogo entre os campos da Educação Musical e da Etnomusicologia, no sentido de que os materiais utilizados em sala de aula ofereçam algumas informações sobre as canções e as culturas a que estas canções se referem. Um guia de pronúncia, a tradução e um texto contextualizando a canção são indicações mínimas (FRAGOSO, 2015, p. 25-35).
} 
-lhes o que eu tinha aprendido. Parecia que eu estava aprendendo sozinha, que eles não estavam dispostos a me ensinar. O mesmo processo aconteceu com quase todas as canções que aprendi na aldeia. E assim foi em outras situações, levando-me a me questionar: por que ficam felizes (crianças e adultos) quando lhes mostro uma canção que aprendi, mas não me ensinam?

O trabalho em campo acontece como um grande quebra-cabeça, com a diferença de que não é o pesquisador quem escolhe a peça que será inserida no quadro. Ao contrário, estas peças vão sendo oferecidas quase que ao acaso, na medida em que as relações vão se construindo e se aprofundando e em que o pesquisador vai se inserindo neste novo contexto. Isso apontou para duas questões relevantes: 1) a relevância de uma metodologia de pesquisa de caráter inventivo, plástico, dinâmico; e 2) a maneira como o grupo pesquisado concebe a aprendizagem interfere no modo como o pesquisador desenvolverá o seu ofício - o de pesquisador mesmo, que é também aprendiz.

Sobre a metodologia, esta já estava delineada: de caráter qualitativo, pressupunha trabalho etnográfico e etnomusicológico, com entrevistas abertas e semiestruturadas e observação participativa. Entretanto, em campo, foram acrescidas mais ferramentas como a art-based research ${ }^{14}$, por conta dos vídeos, desenhos e pinturas feitos, por exemplo.

A dinamicidade que marcou essa metodologia era uma necessidade que Bourdieu já havia apontado ao tratar da invenção metodológica, que se vai moldando pelas relações estabelecidas em campo. Para o sociólogo, essa dinamicidade está associada ao rigor científico, que não deve ser confundido com a rigidez metodológica, que priva o pesquisador de mobilizar as técnicas necessárias e pertinentes durante o trabalho (BOURDIEU, 1989, p. 26).

A fim de que eu obtivesse os dados pretendidos, foi preciso, portanto, inventar um caminho que só caberia naquele contexto. Mesmo assim, meu trabalho foi ficando mais fácil conforme as relações iam se estreitando, de modo que as peças desse quebra-cabeça, que era aprender entre eles, iam se mostrando; e, para que isso acontecesse de fato, isto é, para que eu efetivamente aprendesse aquilo a que me propus aprender, era necessário que eu entendesse como esse grupo concebe o ensino e a aprendizagem, 0 que só seria viabilizado pela vivência. Mas, antes disso, eu precisei entender que a concepção de ensino-aprendizagem entre os Guarani tem a ver com a sua concepção de infância.

\section{As crianças Guarani entre os adultos Guarani}

Sempre que vou à aldeia, minha atenção é desviada para as crianças, principalmente quando estão entre os adultos. O momento em que o coro se apresenta é, para mim, o que melhor representa tanto a concepção de infância quanto de ensino e aprendizagem dos Guarani.

Os corais guarani são formados por crianças e adultos. De um lado ficam os meninos e homens, um ao lado do outro, em ordem de tamanho, com o menor à esquerda. 
Do outro lado ficam as meninas e as mulheres. Assim como o grupo masculino, estas se dispõem uma ao lado da outra, ordenadas por tamanho, com a menina menor à direita. As meninas e mulheres dão-se as mãos, com os dedos entrelaçados. Os meninos e homens, em geral, ficam com as mãos para trás. A rave'i (rabeca), o mbaraka (violão) e o mbaraka mirĩ (chocalho) são tocados pelos homens. Os dois primeiros instrumentos são tocados por adolescentes ou homens adultos. Já o mbaraka mirĩ pode ser também tocado por alguma das crianças, desde que seja do sexo masculino.

O primeiro ponto a ser observado é que crianças e adultos cantam, dançam e tocam juntos. Perguntei, certa vez, ao xeramoĩ, de que maneira as crianças se envolviam nas rezas e rituais na opy. A resposta que tive, e que vi depois, é que são muitas as situações em que as crianças fazem o que os adultos fazem, junto com eles. Há, talvez, alguém se questionando quanto à razoabilidade de crianças participarem de algumas tarefas de adultos. Por isso, são necessários alguns esclarecimentos. O primeiro deles trata da estranheza que as diferenças encontradas na forma como as culturas se organizam provocam. Tal estranhamento acontece com certa frequência, em função do etnocentrismo (LÉVI-STRAUSS, 2000, p. 18; 2012, p. 90). De acordo com Martuccelli (2010, p. 19), este é, inclusive, um "estranho princípio de nossa humanidade comum". No entanto, este olhar autorreferenciado em direção àquele que é diferente precisa ser superado, considerando a intenção de se respeitar as diferenças e de com elas conviver.

O segundo ponto a ser esclarecido tem a ver com o fato de que, para os Guarani, é de extrema relevância que as crianças participem dos cantos. Para eles, é dessa maneira que elas aprenderão não somente as canções e rituais, mas o nhandereko guarani, ou seja, o modo de viver dos Guarani. Em outras palavras, participando destes momentos, as crianças Guarani aprendem a ser guarani. Por esta razão, as crianças não são impedidas de tomar parte nos cantos, nas danças ou mesmo de tocar um instrumento musical. E não importa se a criança já sabe tocar ou dançar ou cantar como fazem os adultos. Se elas desejarem, elas podem participar como sabem. Aos adultos, cabe-lhes fazer. Às crianças, se desejarem, imitar e experimentar.

Disso, sublinho dois aspectos: o respeito pelo que as crianças são capazes de fazer e pelo desejo da criança em fazê-lo. Há, por parte dos Guarani, de acordo com Schaden (1962, p. 67), um "respeito pela personalidade humana e a noção de que esta se desenvolve livre e independente em cada indivíduo". Isso é explicado "pela concepção de alma e reencarnação, que estabelece que o caráter da pessoa é inato, e as crianças seriam muito independentes e respeitadas" (COHN, 2000, p. 47).

O respeito referido por Schaden revela-se na compreensão e no reconhecimento, entre os Guarani, de que os indivíduos têm tempos de desenvolvimento diferentes. $O$ fato de uma criança, por exemplo, ser capaz de saltar de certa altura, e outra, mesmo que da mesma idade, ainda não o fazer, não é motivo para preocupação, como parece ocorrer, por exemplo, em parte das escolas brasileiras, onde se espera que todas as crianças de uma mesma série escolar sejam capazes de realizar as mesmas tarefas cognitivas ou motoras. Isso porque se entende que as crianças só fazem o que estão prontas para fazer. Assim, a criança que ainda não é capaz de saltar, sê-lo-á quando estiver pronta para isso. Além disso, acredita-se que cada indivíduo recebe dons de Nhanderu. 
Nesse sentido, cada um terá maior habilidade que outra em assuntos distintos, não sendo necessário que todos alcancem o mesmo desenvolvimento.

Durante os cantos, então, a criança, se quiser, pode participar deles tocando um instrumento musical ou dançando e cantando, a seu modo, sem interferência dos adultos na maneira como ela executa a atividade. Entende-se, portanto, que se a criança pegou o instrumento, por exemplo, ela o fez porque quis, e é assim, pela vivência e pela imitação, que ela aprenderá.

\begin{abstract}
Como no mundo indígena de um modo geral, as famílias guarani têm seus filhos, e esses filhos sempre ficam com os pais. Não tem creche nem escola como no mundo do jurua, e então tudo se aprende, tudo se sente com a família, na casa, na vivência. As crianças são pessoas que vão copiando as outras pessoas mais adultas do seu lado. Quando fui em uma aldeia do Guarani Mbya lá no Paraguai, vi uma coisa que já não vejo mais aqui na Tenonde e é uma coisa muito especial, muito especial mesmo. As mulheres mais velhas tinham o yrupë'i, que é um tipo de peneira onde se coloca o milho depois de socado, e então vai mexendo, assopra... As mulheres adultas tinham um pilão grande, e as meninas pequenininhas tinham cada qual sua peneira pequenininha, sua madeira pequenininha e seu pilão pequenininho. Elas faziam exatamente o que a mãe fazia. A mãe do lado não falava "é assim!", ou "não, não é assim!". A criança ficava em silêncio, só observando como que desce a madeira, como que mexe o milho na cuia, no pilão pra lá, pra cá. O Guarani aprende vendo, assim... (MIRĨ, 2013, s/p).
\end{abstract}

Nesse sentido, não eram as crianças Guarani que não estavam me ensinando algo, mas era eu quem não estava pronta para aprender. Ao contrário de minhas impressões, os Guarani estavam, a todo tempo, ensinando-me; mas eu aprenderia quando estivesse pronta. E, mais que isso, era preciso que eu quisesse aprender, e isto significava que, para que eu aprendesse, eu precisava observar, experimentar, imitar e fazer, ou seja, isto deveria ser uma necessidade que partisse de mim, não delas. As crianças não me diriam "venha cá fazer isso para que você aprenda", porque elas entendiam que, se eu quisesse mesmo aprender, eu iria até elas por conta própria e, com elas, começaria a fazer, a experimentar.

A experiência, a vivência como meio de aprendizado também é mencionada em pesquisas desenvolvidas entre outras etnias. Por exemplo, para os Bakairi, "desde que acordam, aprendem vivendo". A educação, para este grupo,

[...] se processa através da participação nas atividades da vida cotidiana, das mais aparentemente insignificantes até as mais sagradas. Desde pequenas, as crianças ouvem a narração de mitos, escutam os cânticos sagrados do Kado [...], observam e aprendem a respeitar as regras da vida em sociedade. Crescem ouvindo histórias de lutas de nossos antepassados e, ouvindo-as, alimentam sua autoestima. Aprendemos fazendo junto com os mais velhos, imitando-os, e colaborando nas atividades do dia a dia". (Relato de Darlene Taukane in SILVA, 2002, p. 47). 
Em outra ocasião, assistia à dança dos xondaro ${ }^{15}$. De acordo com os Guarani, esta é uma dança de guerra da qual participam somente os homens. De caráter instrumental, os participantes correm em círculo, uns atrás dos outros, enquanto enfrentam desafios e realizam movimentos rápidos, como pular sobre um obstáculo sustentado por um líder, por exemplo. Não vi crianças muito novas participando dessa dança junto com os adultos. No entanto, nesse dia, uma situação me chamou a atenção: um dos filhos do xeramoĩ da aldeia também participava da dança, e seu filho, de três anos de idade na época, participava com ele. Soube pela avó que o menino gostava muito de dançar, mas, ainda que não houvesse idade mínima para os meninos participarem desta atividade, 0 pequeno não conseguiria acompanhar os adultos. Por isso, seu pai formou, somente com a criança, uma nova roda dentro daquela maior e, ali, os dois dançaram juntos: o pai fazendo os movimentos que deveriam ser feitos enquanto a criança o acompanhava, imitando-o com os mesmos movimentos, mas à sua maneira. Em momento algum seu pai o corrigiu. O menino participava com o pai da dança ao mesmo tempo em que a dança acontecia e junto com os que participavam dela, num processo de aprendizagem contextualizado.

Em outro momento, a caminho da aldeia, recebo a ligação de uma Guarani perguntando-me a que horas eu chegaria à aldeia, pois as crianças estavam começando a dança dos xondaro. Respondi que ainda levaria mais uma hora. "Que pena", ela me disse, "você não vai assistir às crianças dançando, mas vou gravar para você". Imaginei que não puderam esperar que eu chegasse porque talvez estivessem apresentando a dança a alguém, ou mesmo que a dança fizesse parte de alguma situação específica, e que, por isso, não havia como parar e me esperar para assistir. Mas, quando cheguei, contaram-me que o motivo da dança naquela manhã de feriado era para que as crianças aprendessem a dança. Em uma situação declarada de ensino, recolheram as crianças, pintaram-nas com urucum e propuseram a dança. No entanto, quando assisti aos vídeos, não havia nenhum adulto conduzindo ou ensinando as crianças. Elas estavam aprendendo a dançar enquanto dançavam, apontando novamente para o que Jera disse anteriormente: as crianças Guarani aprendem a fazer enquanto fazem.

Macedo (2013, p. 206) conta que, certa vez, pediu aos Guarani que realizassem uma oficina a fim de mostrar a ela como era feito o batismo da erva mate (ka'a nhemongarai). De acordo com a autora, o que era para ser uma apresentação, uma representação do ritual, acabou se transformando no próprio ritual, de modo que ela foi percebendo que aquele "mostrar como se faz foi efetivando-se como um fazer" (ibidem, p. 206). O mesmo aconteceu quando, em minha primeira visita acompanhada do grupo não indígena, as crianças Guarani me ensinaram uma de suas brincadeiras: a mandi'o nhemondoro ("brincadeira da mandioca" ou, traduzido literalmente, "arrancar a mandioca") (FRAGOSO, 2015, p.94), uma brincadeira tradicional da colheita da mandioca.

Enquanto eu acompanhava as crianças Guarani e não indígenas em uma das triIhas da aldeia, um de meus alunos (do segundo grupo) me chamou para ver do que os Guarani estavam brincando. Quando cheguei ao lugar, encontrei "uma criança indígena 
sentada no chão, abraçada à base do tronco de uma árvore, enquanto outra a puxava por trás, tentando, à força, fazer com que se soltasse do tronco" (FRAGOSO, 2015, p. 94). Pedi, em seguida, que me ensinassem a brincar e, ainda que eu fizesse perguntas, tais como "O que eu faço agora?" ou "Em quem eu seguro?", nada me respondiam. Algumas das crianças não indígenas que haviam assistido à brincadeira tentavam me explicar o que eu deveria fazer, mas as Guarani ficavam em silêncio; sequer pediam para eu sentar. De repente, começa a brincadeira:

[...] as crianças sentadas ao chão, enfileiradas e agarradas umas às outras, por trás (abraçando pelo plexo solar), como um trenzinho, sendo que a primeira da fila se agarra à árvore; Alessandra Yva (a criança mais velha) bate na cabeça de cada um e, de repente, puxa a última - que era eu. Então compreendi que eu tinha que segurar muito forte na criança que estava à minha frente, enquanto esta se segurava na que estava à sua frente e, assim por diante, até a primeira criança, a que se segurava na árvore. A Alessandra ia puxando as crianças uma a uma, até que todas fossem arrancadas de onde estavam. (FRAGOSO, 2015, p. 94).

Depois que o jogo acabou, as crianças me contaram que essa era a "brincadeira da mandioca". Mais tarde, os adultos indígenas me disseram que a ideia do jogo é simular a colheita da mandioca, raiz tuberosa bastante difícil de puxar da terra.

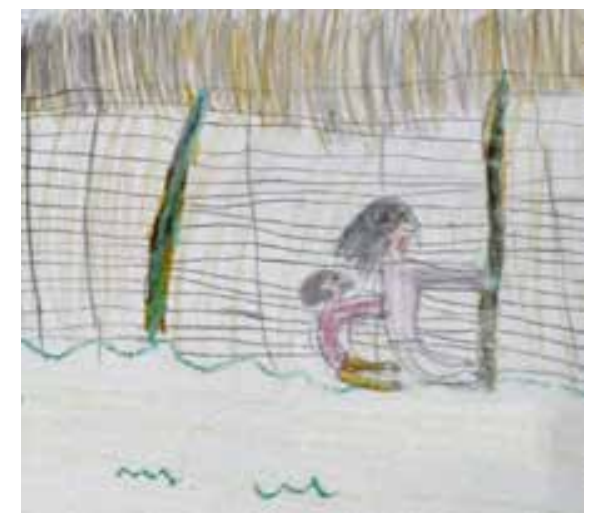

Fig. 2. A "brincadeira da mandioca". Registro feito por uma das crianças não indígenas participantes da pesquisa em seu diário de campo. No desenho estão ela e uma de suas amigas Guarani mais próximas da aldeia brincando de mandi'o nhemondoro (FRAGOSO, 2015, p. 193).

Ao final da brincadeira, perguntei às crianças quem era o vencedor no jogo, mas não tive resposta. Este jogo nos remete ao jogo ideal deleuziano (1974, p. 61): um jogo em que não há vencedores nem perdedores; um "jogo em estado puro, que não conta com regras preexistentes" (BRITO, 2007, p. 44); um jogo que se joga pelo prazer do brincar e que é livre.

O mesmo aconteceu na brincadeira Akuxi ojere. Em roda, as crianças falam os versos Akuxi ojere/Pyáuvy ara py/Uru ojapukai rã/ Oo hoapa! (A cutia dá voltas/ De noite, de dia/ O galo cantou/ A casa caiu!). Na última sílaba do último verso (pa), todos devem se abaixar (FRAGOSO, 2015, p. 54). Quando as crianças me ensinaram esta brincadeira, 
perguntei, ao final dela, o que acontecia com aqueles que não se abaixassem. Elas se olharam e, nitidamente, inventaram uma resposta: "Aí vai para o meio da roda". Entendi que este era mais um jogo que não comportava vencedores nem vencidos e que, naquele momento, elas haviam criado, por causa da minha pergunta, as categorias de vencedores e perdedores.

A infância, entre os Guarani, comporta a ideia de jogo ideal deleuziano, pois é uma infância que permite o jogo livre, sem regras preexistentes, sem vencedores e vencidos. Brito (2007, p. 44), por exemplo, associa o jogo ideal de Deleuze ao brincar infantil, afirmando que este é "o jogo da criança, para quem o jogar, o brincar em si mesmo, é modo de vida que vem e vai, que flui sem vencedores ou perdedores, que é jeito de perceber, de sentir, de viver". Em linha com esta forma de vivenciar a infância, às crianças Guarani é permitido fazer as coisas a seu modo, seja participando dos cantos e das danças ou de tarefas outras: porque estas estão inseridas no contexto dos jogos associados à sua infância, jogos estes assinalados pela liberdade de quem joga somente pelo prazer de jogar.

Contudo, não podem ser desconsideradas as regras sociais e culturais a que estão submetidos os indivíduos. Em outras palavras, ainda que a concepção de infância entre os Guarani permita que o jogo ideal aconteça, tal permissão faz parte das regras sociais que orientam o modo como os Guarani se organizam e vivem. Por exemplo, àqueles não indígenas que chegam à aldeia, a liberdade que marca a infância guarani e que se estende aos processos de ensino e aprendizagem pode, num primeiro momento, dar a impressão de que não há critérios estabelecidos para que a aprendizagem se efetive, como se as crianças estivessem imersas no caos, impedindo-as de se concentrar e de aprender o que precisam; pode-se ainda confundir tal liberdade com desordem e mesmo com descaso tanto por parte daqueles que entendemos que deveriam ensinar quanto dos aprendizes. O mesmo foi observado por Nunes entre as crianças A'uwe-Xavante. Para a pesquisadora, esta

[...] aparente desordem ou falta de ordem, ou, antes, uma ordem vivida de outro modo, imersa num espírito lúdico, espontâneo e sem compromisso, [...] pode estar no cerne de todo um processo educacional. Afinal, o que pode parecer caótico e sem regras obedece a esquemas rigorosos de construção e transmissão de saberes, e é desse modo que as crianças os incorporam e deles vão tomando consciência. (NUNES apud NUNES, 2002, p. 72, grifo nosso).

O processo de ensino e aprendizagem entre os Guarani está alicerçado em uma concepção de infância que abrange e permite a liberdade, o brincar livre e o jogo ideal, e é sobre essa base que ele se realiza. Nesse sentido, as crianças se sentem livres para participar a seu modo da vida na aldeia, de modo que o mundo guarani não estará à espera delas quando se tornarem adultas, mas dele elas já se apropriaram durante a infância.

\section{Conclusões}

Perguntei, certa vez, a um dos filhos do xeramoĩ como foi que ele aprendera a tocar violão, ou, em guarani, o mbaraka. "Eu vi. Vi e aprendi", respondeu-me ele (FRAGOSO, 2015, p. 178). 
O verbo "ver", neste contexto, não significa "olhar", como quem "olha" algo para que depois seja capaz de imitar. Mais que isso, aqui ele é entendido como "viver". Nesse sentido, os Guarani aprendem vivendo: "Eu vivi. Vivi e aprendi". Nesse sentido, a razão por que os Guarani não me ensinavam suas canções consistia no fato de que eu não percebia que estavam me ensinando algo. Ao contrário, as crianças Guarani, pacientemente, esperavam de mim que eu vivesse, experimentasse, vivenciasse para que eu aprendesse. Mas isso só aconteceria se eu sentisse a necessidade de fazer, de experimentar, de viver. Quando eu entendi isso, passei a fazer mais e, portanto, a aprender mais. No entanto, a descoberta de como "aprender a aprender" só poderia acontecer em campo, entre os Guarani, afinal, era necessário que, primeiramente, eu apreendesse a cultura guarani para que chegasse a essa conclusão; aliás, tal apreensão, igualmente, só se viabilizaria pela vivência, pelo viver.

Quando Jade repetia a canção, ela o fazia para que eu aprendesse, e, quando cantei com ela, não importou a qualidade da minha pronúncia, nem mesmo a ausência de sentido no que eu cantava, porque eu estava aprendendo e ela estava me ensinando. Além disso, a canção só faz sentido quando cantada por completo, por isso, a cada repetição, era preciso cantar a canção inteira, e eu podia ir cantando os trechos que eu já entendia. Não era preciso que eu cantasse a canção inteira, porque eu estava no papel de aprendiz. Aquela que me ensinava, porém, deveria me ensinar fazendo, e a canção era feita daquele modo: inteira, com toda a complexidade que eu pudesse identificar. Assim como no caso da dança dos xondaro, o pequeno guerreiro fazia o que era possível que fizesse, mas a dança, por meio de seu pai, acontecia por completo. E o menino pareceu se sentir da mesma forma que eu me senti quando cantei com a Jade, era parte daquele momento.

\section{Agradecimentos}

Às crianças Guarani da aldeia Tenondé Porã e suas famílias; às crianças do Tico-tico Coral Infantil. À Carob House pela contribuição com esta pesquisa. Aguyjevete!

\section{Referências}

BOURDIEU, Pierre. O poder simbólico. Tradução Fernando Tomaz. Rio de Janeiro: Bertrand Brasil, 1989.

BRITO, Maria Teresa Alencar de. Por uma educação musical do pensamento: novas estratégias de comunicação. Tese (Doutorado em Comunicação e Semiótica) - Pontifícia Universidade Católica de São Paulo, São Paulo, 2007.

COHN, C. A criança indígena: a concepção Xikrin de infância e aprendizado. Dissertação (Mestrado em Antropologia Social) - Faculdade de Filosofia, Letras e Ciências Humanas, Universidade de São Paulo, São Paulo, 2000. 
DELEUZE, Gilles. Lógica do sentido. Tradução Luiz Roberto Salinas Fortes. São Paulo: Perspectiva, Ed. da Universidade de São Paulo, 1974.

DOOLEY, Robert A. (Organização, compilação e assistência linguística). Léxico Guarani, dialeto mbya: versão para fins acadêmicos. Porto Velho: Sociedade Internacional de Linguística, revisão de novembro de 1998.

FRAGOSO, Daisy Alves. Entre a opy e a sala de música: arranjos entre crianças guarani Mbya e crianças não indígenas. 2015. Dissertação (Mestrado em Artes) - Escola de Comunicações e Artes, Universidade de São Paulo, São Paulo, 2015.

LÉVI-STRAUSS, Claude. Raça e história. 6. ed. Lisboa: Editorial Presença, 2000.

. A antropologia diante dos problemas do mundo moderno. Tradução Rosa Freire d'Aguiar. São Paulo: Companhia das Letras, 2012.

MACEDO, Valeria. De encontros nos corpos guarani. Ilha - Revista de Antropologia, UFSC, Santa Catarina, v. 15, n. 2, p. 181-210, jul./dez. 2013.

MARTUCCELLI, Danilo. ¿Existen indivíduos en el Sur? Santiago de Chile: LOM Ediciones, 2010.

MIRĨ, Jera Poty. Jera Poty Mirĩ, liderança guarani e vice-diretora da Escola de Educação Indígena Guyra Pepo, na aldeia Tenondé Porã [18 dez. 2013]. Entrevistadoras: Alice Haibara, Joana Cabral e Valéria Macedo.

NUNES, Ângela M. No tempo e no espaço: brincadeiras das crianças A'uwe-Xavante. In: SILVA, Aracy Lopedas da; NUNES, Angela; MACEDO, Ana Vera Lopes da Silva (Orgs.). Crianças indígenas: ensaios antropológicos. São Paulo: Global, 2002. p. 64-99.

SCHADEN, Egon. Aspectos fundamentais da cultura guarani. São Paulo: Difusão Européia do Livro, 1962.

SILVA, Aracy Lopes da. Pequenos "xamãs": crianças indígenas, corporalidade e escolarização. In: SILVA, Aracy Lopes da; NUNES, Angela; MACEDO, Ana Vera Lopes da Silva (Orgs.). Crianças indígenas: ensaios antropológicos. São Paulo: Global, 2002. p. 37-63. 